\title{
Legal status experience of foreign students returnees from immigration center: A case study
}

\author{
Adekalu Samuel Olutokunbo ${ }^{1}$, Idowu Grace Tanimoonwo ${ }^{1}$, Oluwaseyitan Rotimi Cephas ${ }^{2}$ \\ ${ }^{1}$ Faculty of Educational Studies, Universiti Putra Malaysia, Selangor, Malaysia. \\ ${ }^{2}$ School of Business Management, Linton University College, Negeri Sembilan, Malaysia.
}

\section{Email address:}

toksadekalu01@yahoo.co.uk (Adekalu S.O.)

\section{To cite this article:}

Adekalu Samuel Olutokunbo, Idowu Grace Tanimoonwo, Oluwaseyitan Rotimi Cephas. Legal Status Experience of Foreign Students Returnees from Immigration Center: A Case Study. Science Journal of Education. Vol. 2, No. 5, 2014, pp. 152-157.

doi: $10.11648 /$ j.sjedu.20140205.13

\begin{abstract}
This study presents a qualitative insight of legal status experience of foreign students' returnees from immigration center. Convenience sampling was applied in the study, and in-depth semi-structured interview was adopted to collect specific data among selected eleven (11) undergraduate foreign students, studying at a private university college, who were released from leggeng immigration deportation camp, Negeri Sembilan, Malaysia. Data were analyzed, and findings as themes were developed. Results of the study were classified into two categories. The first category indicates, the legal status challenges encountered by the students in the university. The second category reveals the students experience in the deportation camp. The study recommends with remarkable conclusion among others; initiatives to improve immigration collective services, roles of educators and school administration on foreign students' supports services, and further suggested with a clarion call for more government supports, to improve the conditions of immigration deportation camp in Malaysia.
\end{abstract}

Keywords: Foreign Students, Legal Status, Student Pass/Visa, Malaysia

\section{Introduction}

Educators play a vital role in ensuring continuity to foster great awareness of foreign collaboration in the academic industries which serves as most institutions strategy to sustain and remain active in this complex world of students experiences (Komives, 2003). This is because, in academic industries, the testimonies of educators' success cannot be determined, without the academic and non-academic achievements of the students, in this modern age, when considering the various benefits that foreign students bring, to the host country such as, socio-cultural development, economic, political, substantial income, and intellectual advantage (Lee, 2007).

However, there are certain factors that compel most foreign students to seek for educational empowerment outside the purview and jurisdictions of their respective home countries. These factors include, but not limited to: quality of education system, low tuition/waiver of fees, scholarship/research grants availability, flexible admission requirement/immigration policy, inter-governmental foreign relations, political/sociocultural ties, religion similarities, and job opportunity, during and after study, in the host countries (skinner \& Shenoy, 2003; Adekalu, Ismi \& Turiman 2013).

According to Adekalu et al., (2013), foreign students are defined as those with different national identities and characteristics such as, background, cultural heritage, religion, race, and gender who are eligible to have the minimum and maximum admission entry requirements and adequate resource to seek for educational empowerment outside the purview of their nation's boundaries, from an approved academic programme, that is recognized by the host institution, and other educational authorities worldwide. Expectedly, studying in the foreign countries, may give a different lifestyle and set of experiences with focus to the case of foreign students in Malaysian institutions of higher learning.

\section{Statement of the Problem}

The current challenges confronting foreign students in government and private universities in Malaysian institutions of higher learning, with regards to the studentship legal status related to student pass/visa renewal, are nothing but distress 
to the educators, foreign students, parents, government, international organizations and stakeholders who are directly involved in students' academic status (Adekalu et al., 2013). Though, there are scant data that are available as to whether foreign students experience greater difficulty in the renewal of student pass/visa in most developed and developing countries institutions of higher learning. Limited amount of research revealed certain distresses and level of imbalance often encountered, by foreign students in the renewal of their students pass/visa (Larendadran, 2013; Adekalu et al., 2013). The gap in the relevant issues regarding legal status of foreign student pass/visa renewal in Malaysia context has not been thoroughly explored, which makes this research imperative, and warrants further research.

\section{Research Objective and Questions}

The main objective of this study is to explore the legal status experience of foreign students' returnees from immigration deportation center in Malaysia, with particular focus on private university college. Also, this study is pilot basically with two research questions; First, to what extent do foreign students experience challenges in the renewal of student pass/visa in Malaysia? Second, to what extent has their experiences, in the immigration deportation camp affected their careers either positively, negatively or both?

Thus, it is strongly believed, that the conclusion reached in this study, will add to the existing academic body of knowledge, and will serve as a clarion call for the government, the educators, the stakeholders, the policy makers, and the general public, in the quest for foreign students to have positive laudable academic experience, to share with the international communities.

\section{Literature Review}

Academic and non-academic related matters of foreign students have been discussed in the literature from broader perspectives. Most issues addressed with reference to foreign students in both conceptual and empirical findings of past researches include, but not limited to: scholarship academic experiences, choice of study destinations, host country experience, methods of teaching and learning, loneliness and isolation, internationalization, adjustment and coping strategies, culture shock, language barrier, financial problems, rapid changing of identity, inadequate supports, alienation and crises at home, family self-expectation, foreign students service supports (Adekalu et al., 2013; Adekalu \& Oludeyi, 2013; Chong \& Amli, 2013; Anh Le, 2010; Deakins, 2009; Leask, 2009; Rosenthal, Russell, \& Thomson, 2008; McClure, 2007; Mitchell, Greenwood, \& Guglielmi, 2007; Neri \& Ville, 2007; Hanassab, 2006; Klomegah, 2006).

Chong Pui Lee (2014), revealed some challenges faced by educators to attract the set expected target of foreign students to their institutions like, lack of facilitates to accommodate the needs of foreign students, problem with students visa requirement, drop-out and compliance to rules and regulation, while they are in Malaysia without committing crimes or social offence. Hence, very little is known about the studentship legal status and the challenges confronted by foreign students with particular focus on Malaysia context.

\section{Methodology}

\subsection{Data Collection}

Semi-structured interview were employed to gather the data needed for the case study. The semi-structured interview, revealed the richness of the data through the use of systematic probing procedures. The interviews focused on gathering the necessary information on the legal status experience of foreign students' returnees from immigration Centre in Malaysia.

The Participants interviewed were Eleven (11) purposive selected undergraduate foreign students studying at the Linton University College, Malaysia who were arrested on the campus environment, by Malaysia Immigration Authorities, and detained for the duration of two (2) to six (6) weeks, at the leggeng immigration deportation camp, in Negeri Sembilan, Malaysia.

The participants' age ranges between 21 to 32 years. Ten (10) of the participants were male, and one (1) female. Seven (7) of the participants were from West Africa, two (2) from East Africa and two (2) South East Asia countries.

Majority of the participants were interviewed in their campus hostels. The duration for each interview was between, one hour and twenty minutes. All interviews were tape recorded, and data were transcribed and analyzed with guided qualitative principles. The whole data gathering process took three (3) months to accomplish. The final report of the study was completed during the second week of September, 2014.

\subsection{Data Analysis}

Table 1. Main Themes

\begin{tabular}{|c|c|}
\hline & Themes \\
\hline $1^{\text {st }}$ category & $\begin{array}{l}\text { * Missing of students' regular passports. } \\
\text { * Special pass. }\end{array}$ \\
\hline Challenges of Students & * Overstay students' validity. \\
\hline Legal Status & $\begin{array}{l}* \text { Medical examination. } \\
* \text { Supporting documents }\end{array}$ \\
\hline $2^{\text {nd }}$ category & $\begin{array}{l}\text { Themes } \\
* \text { Language barrier }\end{array}$ \\
\hline $\begin{array}{l}\text { Experience in } \\
\text { deportation camp }\end{array}$ & $\begin{array}{l}* \text { Access to communication } \\
* \text { Lack of basic needs } \\
* \text { Denial of Rights to education }\end{array}$ \\
\hline
\end{tabular}

The analysis of data undertaken in the research was done manually rather than through the use of coding software. The authors used four steps process. The first step, in the data analysis was to immediately transcribe the field note and tape recording, taken during the interviews. The second step was to identify the keywords related to the major questions asked, 
during the interviews, and each of the keywords was arranged in themes. The third step was to review the findings, through an independent researcher. In the final step, participants' transcripts of recordings were prepared, and they were further consulted to review and double-check, the interpretations of the research findings, and the information were kept confidential.

\section{Results and Discussion}

Results of this study are divided into two (2) categories, based on the research questions. The first category deals with challenges, while the second category discusses the participants' experience. The participants involved encountered five (5) main challenges on their studentship legal status in the renewal of student pass/visa and four (4) themes was developed based on the students experience in the immigration deportation camp.

\subsection{Challenges of Students Legal Status}

Based on the results obtained from the study, one of the challenges experienced, by foreign students on legal status is the missing of students' regular passport. Holding a proof of citizenship is highly important to foreign students, in a host country. One of the participants stated that, "I was released from the deportation camp, after four weeks, by my school representative; without my international passport, and I was shocked when my agent informed me that I have to get a police report with another passport from my embassy". Likewise, other participants revealed that, it was the day of their release from the camp that they were able to see their international passports, since submission. The results show, the recurring dangers of countries abusing the sovereignty right and obligations of diplomatically protect citizens (Natoli, 2010).

The results of the interview also indicate that, two participants released from the camp, have valid student pass/visa and nine were released with immigration special pass, which still required the school management to submit a fresh application to the Malaysia immigration department to process their student pass/visa. According to the results of the study, majority of the participants revealed that, "they have no idea of what is special pass and their expectation is to renew their existing student pass/visa".

Also, issues of overstayed students' validity were revealed from the results of the study, as the major challenge in the renewal of the students pass/visa. Aside the two participants released with valid students pass/visa, the remaining nine participants have already overstayed, which made them illegal migrants according to the immigration policy. The result further indicates that, "the students have submitted their passports to the school for the purpose of student pass/visa renewal earlier on, or, before the expiring date of their existing student pass/visa". The result further shows that, the students were not well informed regarding the process and current status of their students pass/visa. Eight of the participants said, the constant reply from the school facilitators in-charge of students pass/visa is "still in process" In the manner of Wang (2007), foreign students services providers are required to have the needful quality and knowledgeable experience to assist students with proper orientations for the new rules and regulation of immigration visa policy and this results closely compliment the literatures, (Lu, 2001; Chong, 2014).

According to the results of the study, medical examination is also identified as a challenge in the delay of student pass/visa. All the participants revealed that, they are required to go for medical examination yearly, before they could be eligible to renew their exiting student pass/visa, by the Malaysian immigration policy. These results richly support the previous literature. In a research conducted by Adekalu et al., (2013), revealed that, factors such as, student's results, attendance, medical examination are prerequisites for student pass/visa in Malaysian institutions of higher learning.

Challenge of supporting documents based on the results revealed by the participants indicate that, Education Malaysian Global Agency (EMGS) who serves as the authorized regulatory body issuing student pass/visa often required adequate supporting documents such as, students medical examination reports, student attendance, students results, institution support's letter on the students current status. Some of the participants revealed that, "Education Malaysian Global Agency (EMGS) website often shows their student pass/visa processing status as institution supporting documents pending". Hence, the expectation of Malaysia Government to attract 200,000 foreign students, by 2020 (Malaysia Ministry of Higher Education, 2011) and with the challenge encountered by foreign students on pass/visa renewal, as indicated by the participants is a reflection to support the position of Larendaran (2013), on the difficult experienced by the foreign students on visa/pass renewal in Malaysian institutions of higher learning.

\subsection{Experience in Deportation Camp}

The results of second category show the experience of students in the immigration deportation camp based on the second research question. Language barrier in terms of communication with other detainees and authorities in the camp is an unfamiliar experience for the students. The involved participants stated that, detainees from other nationalities do not speak English language except few of them, and the English expression of most of the officers in the camp is not clear. Researchers have revealed in literature that, language barrier is one of the identified challenge most foreign students experience in terms of the teaching method and communication with local people in the host countries (Al-zubaidi \& Richards, 2009; Alavi \& Mansor, 2011).

Also, access to communication with relevant authorities in the college was identified as another experience of the student in the camp. Participants revealed that, during their stay in the camp "we were not allowed communication with our college, and most especially our parents back home, and it's like we lived in a different world". 
In this study it was discovered that, the involved participants, did not have access to basic needs for living such as good food, medication, good water and accommodation while staying in the camp. In a research conducted by $\mathrm{Lu}$, (2001) with reference to foreign students, factors like accommodation and food is seen as problematic challenges, for most foreign students upon their arrival to the United States. The participants revealed that, their lives were unsafe due to the poor accommodation facilities, poor food and water, without medications provided for them, by the immigration authorities in the camp.

Finally, denial of rights to education in the camp as revealed by the involved participants was a sad experience, to the students. Ten of the participants confessed that, they have set back in their studies "at the time they were released from the camp back to the school, we have already missed classes, continuous assessments, examinations; we are now to retake the courses next semester". Based on the response, the right based education as spread around the world describing governmental human rights obligations to make education available, accessible, acceptable and adaptable by UNESCO, 2003 is violated in this regard (Tomasevski, 2004).

\section{Conclusion}

With reference to the main objective and research questions, it is worthy to note based on the results of this study that, foreign students experience challenges, on legal status related to student pass/visa renewal, in the host country. Factors such as, missing of student regular passport, extension of overstayed students' validity, temporary special pass, EMGS pending supporting documents, student yearly medical examination, are the major challenges in the delay of the student pass/visa. Also, language barrier, communication, lack of basic needs coupled with depriving of the students right to education in the deportation camp is an unfamiliar experience to the involved students.

\section{Scope for Further Research}

This study has been designed and carried out with specified objective to explore the legal status experience of foreign students' returnees from immigration center at one private college. The results do not reflect the status of generalization to other institution of higher learning. However, sample size and limitations of this study warrants further research in contribution to the existing academic body of knowledge, by enlarging the sample size, methodology, institution location, to mention but few.

\section{Recommendations}

Considering the results of this study, initiatives to improve studentship legal status of foreign students with regards to student pass/visa renewal in Malaysia are recommended as follows:

1. A cordial workable arrangement between EMGS and the institution: There is a need for a cordial workable system between the agencies saddled with the responsibility of securing visa for foreign students, to facilitate quick discharge and delivery of necessary services needed for the students legal status.

2. Flexible visa renewal processing: The immigration department Malaysia should operate a flexible visa renewal processing especially as regards the student visa, it will reduce the stress and challenges encountered by foreign students, educators, parents, government, international organizations and stakeholders who are directly involved in students' academic status. One-time visa can be considered and approved based on the duration of each student's course; it will make a great difference in resolving this problem.

3. An effective communication: The foreign students should be afforded the privilege of easy access to their school authorities, for proper procedure for their timely release.

4. An improved state of the deportation camp: The basic needs such as good food, medication, good water, and accommodation should be available, not only for the detained students, but other refugees.

5. Foreign Students Rapid Service response: There is a necessity for institution to develop the system of rapid response to students' needs, in all related matters. This is necessary considering the fact that schools activities go on while students are still in immigration lock-up.

6. Realistic Pre-arrival students' orientation: The school agents that are saddled with the duty of students' recruitment should be honest, in furnishing and equipping the students, with vital and realistic information, about the realities on the ground, in their country, both academic and non-academic issues, that may likely affect the quality of their studentship. This will prepare the students with the right mind frame for any imminent challenge, they may likely face, in the course of their study, and also enable them to make an informed decision, concerning their choice of institution.

\section{References}

[1] Adekalu, S.O., Ismi, A.I. \& Turiman. S. (2013). Academic Experience of International Students on Scholarships in Malaysian Universities: The Case of A Private University College. International Journal of Learning \& Development, Macrothink Institute, USA. Vol.3, No.6. Pp 7-18.

[2] Adekalu, S. O., \& Oludeyi, O. S., (2013). Edutourism: The Nigeria Educational Challenges and International Students Choice of Study in Nigerian Universities. International Journal of Academic Research in Progressive Education and Development. Volume 2, Issue 4.Pp. 53-63

[3] Alavi, M. \& Mansor, S. M. S. (2011). "Categories of Problems among International Students in University Technology Malaysia." Procedia-Social and Behavioral Sciences 30: 15811587 
[4] Al-Zubaidi, K., \& Rechards, C. (2009). Arab Postgraduate Students in Malaysia: Identifying and Overcoming the Cultural and Language Barriers. Arab World English Journal and Service.

[5] Anh Le, (2010). Making the Great Journey: International Students' experiences at the University Of NebraskaLincoln.Educational Administration. USA.

[6] Chong Pui Lee (2014), Internationalization of Higher Education: A Literature Review on Conpetency Approach. International Journal of Asian Social Science. 4(2): 258-273.

[7] Chong P. Y. \& Amli H. A. M., (2013). International students' learning experience at private higher education institutions in Malaysia. Proceeding of the Global Summit on Education. pp. 298-312

[8] Deakins, E. (2009). Helping students' value cultural diversity through research-based teaching.Higher Education Research \& Development, 28(2), 209-226.

[9] Hanassab, S. (2006). Diversity, international students, and perceived discrimination: Implications for educators and counselors. Journal of Studies in International Education, 10(2), 157-172.

[10] Klomegah, R. Y. (2006). Social factors relating to alienation experienced by international students in the United States. College Student Journal, 40(2), 303-315.

[11] Komives, S., \& Woodard, D., et al. (2003). Student services: A handbook for the profession. San Francisco: Jossey-Bass.

[12] Lavendadran, G. (2013), foreign students in a dilemma: FMT News 6th of September. Received online on 24th August, 2014. From http: //www.freemalaysiatoday.com/category/nation/2013/09/06/for eign-students-in-a-dilemma/

[13] Leask, B. (2009). Using Formal and Informal Curricula to Improve Interactions between Home and International Students. Journal of Studies in International Education, 13(2), 205-221

[14] Lee, J. J. (2007). Neo-racism toward international students. About Campus, 11(6), 28-30.
[15] Levitz, R., \& Noel, L. (1989). Connecting students to institutions: Keys to retention and success. In M. L. Upcraft, J. N. Gardner, \& Associates, The freshman year experience (pp. 65-81). San Francisco: Jossey-Bass.

[16] Lu, M. (2001). International Students and University Support Services.

[17] McClure, J. W. (2007). International graduates' cross-cultural adjustment: Experiences, coping strategies, and suggested programmatic responses. Teaching in Higher Education, 12(2), 199-217

[18] Ministry of Higher Education Undated, 2011. Higher education statistics. Available from http://www.mohe.gov.my/web_statistik/

[19] Mitchell, S. L. Greenwood, A. K., \& Guglielmi, M. C. (2007). Utilization of counselling services: Comparing international and U.S. college students. Journal of College Counseling, 10(2), 117

[20] Natoli, K. (2010), Abuse of Right Doctrine Weaponizing Nationality: An Analaysis of Russia's Passport Policy in Georgia. Boston University International Law Journal. Vol. 28: 389-417.

[21] Neri, F. \& Ville, S. (2008). Social capital renewal and the academic performance of international students in Australia. The Journal of Socio-Economics, 37, 1515- 1538.

[22] Rosenthal, D. A., Russell, J., \& Thomson, G. (2008). The health and well-being of international students at an Australian university: Higher Education: The 101 International Journal of Higher Education and Educational Planning, 55(1), 51-67.

[23] Skinner, K. G., \& Shenoy, A. (2003). International students: In J. W. Guthrie (Ed.), Encyclopaedia of education; (2nd ed.). New York: Macmillan Reference USA.

[24] Tomasevski K. (2004). Manual on right-based Education. Global human right requirements made simple. Bangkok: UNESCO Bangkok, Pp. 60.

[25] Wang, Y. (2007). International student' satisfaction with international student services and their collage experience. Doctoral dissertation, Dowling College, 2007.UMINo.3288342, V68-11A, Pp. 149 


\section{Biography}

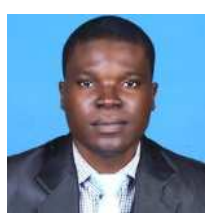

Adekalu Samuel Olutokunbo holds a National Diploma in Public Administration, from Federal Polytechnic Idah, Nigeria (2005). He obtained his First Degree in Sociology from Tai Solarin University of Education, Nigeria (2010) and completed his National Youth Service Corps (NYSC) in Abuja, Nigeria (2011). He is an academic scholar of Petroleum Technology Development Fund (PTDF), Nigeria, to complete his Second Bachelor's Degree in Business Information Systems at Pertama Institute of Technology in collaboration with University of East London, UK (2014). He completed his Master's Degree (2013) and currently a Ph.D. student both in Human Resource Development at the Universiti Putra Malaysia.

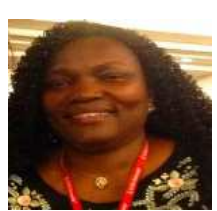

Idowu Grace Tanimoonwo is a trained teacher, who holds a Nigerian Certificate in Education (NCE English/Yoruba) from the College of Education, Ikere-Ekiti, Ekiti State, Nigeria (1981) after which she completed her National Youth Service Corps (NYSC) in Oyo State, Nigeria (1982). She further proceeded to the University of Lagos, Nigeria, where she obtained her Bachelor and Master's Degrees in Guidance and Counseling between 1983 to 1987 respectively. She is currently a Ph.D. student in the field of Counseling Psychology, specializing in Family Therapy at the Universiti Putra Malaysia. She is a multi-linguist, married with children.

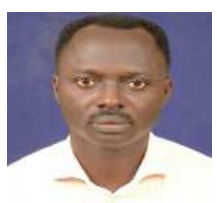

Oluwaseyitan Rotimi Cephas graduated with Bachelor's Degree in Economics from Obafemi Awolowo University, Ile-Ife, Osun State, Nigeria (1995). Having completed his National Youth Service Corps (NYSC) in Kogi State, Nigeria (1996), he worked for 18 years during which he did the Advance leadership regional training with Haggai Institutes of Leadership. He joined Linton University College, Malaysia, in 2012 where he obtained his Master of Business Administration (MBA) in February 2014. He has visited and attended conferences in the United States of America, United Kingdom, Germany, France, Belgium, China, Singapore, Kenya, Ghana, and Republic of Benin among others. 